\title{
Gene Transfer
}

National Cancer Institute

\section{Source}

National Cancer Institute. Gene Transfer. NCI Thesaurus. Code C20185.

Incorporation of new DNA into an org anism's cells, usually by a vector such as a modified virus. Used in gene therapy.(From Human Genome Project Information). 